Primljen / Received: 19.5.2015. Ispravljen / Corrected: 30.8.2016. Prihvaćen / Accepted: 25.9.2016. Dostupno online / Available online: 10.12.2016.

\section{Passenger terminal extension structure at Split Airport}

Authors:

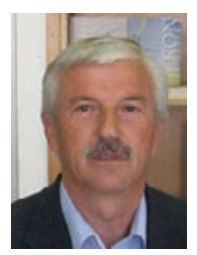

Prof. Jure Radnić, PhD. CE

University of Split

Faculty of Civil Engineering, Arch. and Geodesy jure.radnic@gradst.hr

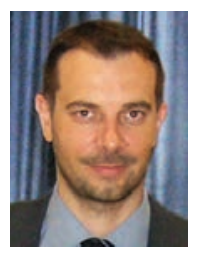

Prof. Domagoj Matešan, PhD. CE

University of Split

Faculty of Civil Engineering, Arch. and Geodesy domagoj.matesan@gradst.hr

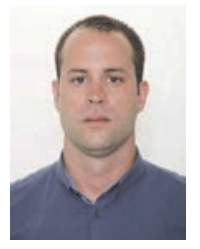

Ivan Banovič, MCE

University of Split

Faculty of Civil Engineering, Arch. and Geodesy ivan.banovic@gradst.hr

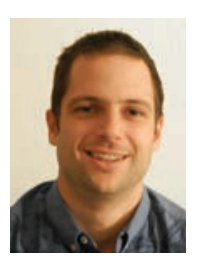

Domagoj Buklijaš-Kobojević, MCE University of Split

Faculty of Civil Engineering, Arch. and Geodesy domagoj9638@gmail.com
Professional paper

\author{
Jure Radnić, Domagoj Matešan, Ivan Banović, Domagoj Buklijaš-Kobojević
}

\section{Passenger terminal extension structure at Split Airport}

The main load-carrying structure, to be built as an extension to the passenger terminal building at Split Airport, is presented in the paper. The structure is complex and comprises various types of facilities (building, bridge, membrane shed), various load-bearing systems (space truss, space frame, dome, tensioned cable, tensioned membrane), various materials (reinforced concrete, structural steel, laminated wood, canvas, steel cable), and different activities (new construction, rehabilitation). When creating load-bearing structural assemblies, a significant emphasis was placed on architectural shaping. Structural design was made in accordance with prevailing regulations, standards, and rules of professional practice, at an advanced technical level.

Ključne riječi:

Split Airport, passenger terminal, extension, structure

Stručni rad

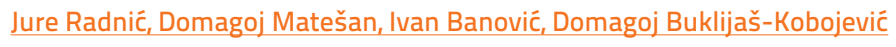

\section{Konstrukcija dogradnje putničkog terminala Zračne luke Split}

U radu je prikazana glavna nosiva konstrukcija dogradnje putničkog terminala Zračne luke Split. Konstrukcija je složena i obuhvaća različite tipove građevina (zgrada, most, membranski trijem), različite nosive sustave (prostorna rešetka, prostorni okvir, kupola, napeto uže, napeta membrana), različita gradiva (armirani beton, konstrukcijski čelik, lamelirano drvo, platno, čelično uže) i različite zahvate (novogradnja, rekonstrukcija). Pri kreiranju nosivih sklopova konstrukcija, bitan utjecaj su imali zahtjevi arhitektonskog oblikovanja. Projekt konstrukcija je izrađen u skladu s propisima, normama i pravilima struke, na suvremenoj tehničkoj razini.

Ključne riječi:

Zračna luka Split, putnički terminal, dogradnja, konstrukcija

Fachbericht

Jure Radnić, Domagoj Matešan, Ivan Banović, Domagoj Buklijaš-Kobojević

\section{Konstruktion des Passagierterminalanbaus am Flughafens Split}

In dieser Arbeit wird das Haupttragwerk des Passagierterminalanbaus am Flughafen Split dargestellt. Die Konstruktion ist komplex und umfasst verschiedene Typen von Bauwerken (Gebäude, Brücke, Eingangsmembrane), verschiedene Tragwerkssysteme (räumliches Fachwerk, räumlicher Rahmen, Kuppel, gespanntes Seil, gespannte Membrane), verschiedene Baustoffe(Stahlbeton, Baustahl, lamelliertes Holz, Textil, Stahlseil) sowie verschiedene Eingriffe (Neubau, Umbau). Beim Entwurf der Tragwerkselemente hatten die Anforderungen der architektonischen Gestaltung wichtigen Einfluss. Das Tragwerk wurde gemäß Vorschriften, Normen und Regeln der Ingenieurskunst auf zeitgemäßem technischem Niveau entwickelt.

Ključne riječi:

Flughafen Split, Passagierterminal, Anbau, Konstruktion 


\section{Introduction}

In recent years, Split Airport transport figures have been steadily increasing, so that as many as 1,955,000 passengers have been transported via this airport in 2015. Due to pronounced peak load traffic during the high tourist season, the capacities of the existing passenger terminal have proven to be insufficient to ensure a proper level and quality of services. According to the Split Airport development plan prepared by the Dutch company NACO (Netherlands Airport Consultants B.V., No. 071229, dated 18 July 2005) based on the analysis of current situation, the projection of traffic growth, and the proposals presented by competent services of the Split airport, the passenger terminal building is to be extended in accordance with an increase in airport transport figures. By rehabilitation and extension of passenger terminal at the Split Airport, the capacities of this airport will be harmonized with the expected traffic demand, a high level of safety and quality of services will be achieved, and conditions will be met for realisation of EU standards (Schengen criteria) for international cross-border traffic. The luggage inspection level compliant with the STANDARD 3 EDS, specified by the EU, will also be reached. A new parking space for passenger cars and buses, with the bus terminal link with passenger terminal via a closed pedestrian overpass over the national road D409, will also be constructed. The architectural design for this rehabilitation and extension project was prepared by VV project d.o.o. - Split, and the authors are Ivan Vulić, M.Arch. and Ivan Radeljak, M.Arch. The existing Split Airport is located immediately to the north of the national road D409 (old Split to Trogir road), and it occupies an area of approximately 95 hectares. The new design calls for extension of the airport complex to include the area south of the D409, and so the total airport area would amount to approximately 105 hectares. The view of the airport after the proposed expansion and rehabilitation is presented in Figure 1.

Based on the new design, the following principal facilities will inter alia be realised (Figure 2 ):

- to the north of the D409

- rehabilitation of the existing passenger terminal building and the existing shed in front of the building

- construction of a new passenger terminal building

- construction of a pedestrian overbridge above the D409; its role is to connect existing facilities with new facilities situated on the south side of the road

- construction of a pedestrian overbridge to establish connection between the new building and the existing apron
- to the south of the D409

- construction of a parking lot for passenger cars

- construction of a bus terminal building

- construction of a shed in front of the bus terminal building

The extension and rehabilitation of the passenger terminal is a complex project, formed of several functionally and technologically connected structures. The plan area of all horizontal structures of the new extension project amounts to approximately 55,000 square meters, and the rehabilitation of the existing building will be conducted on an area occupying approximately 10,500 square meters.

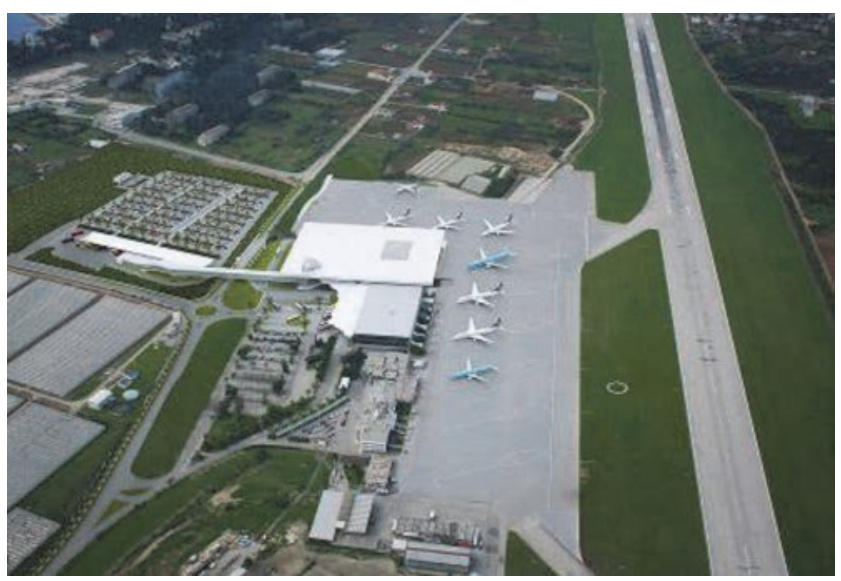

Figure 1. View of Split Airport after rehabilitation and expansion

The size of the existing passenger departure/arrival building will remain unchanged, but the contents of the building will

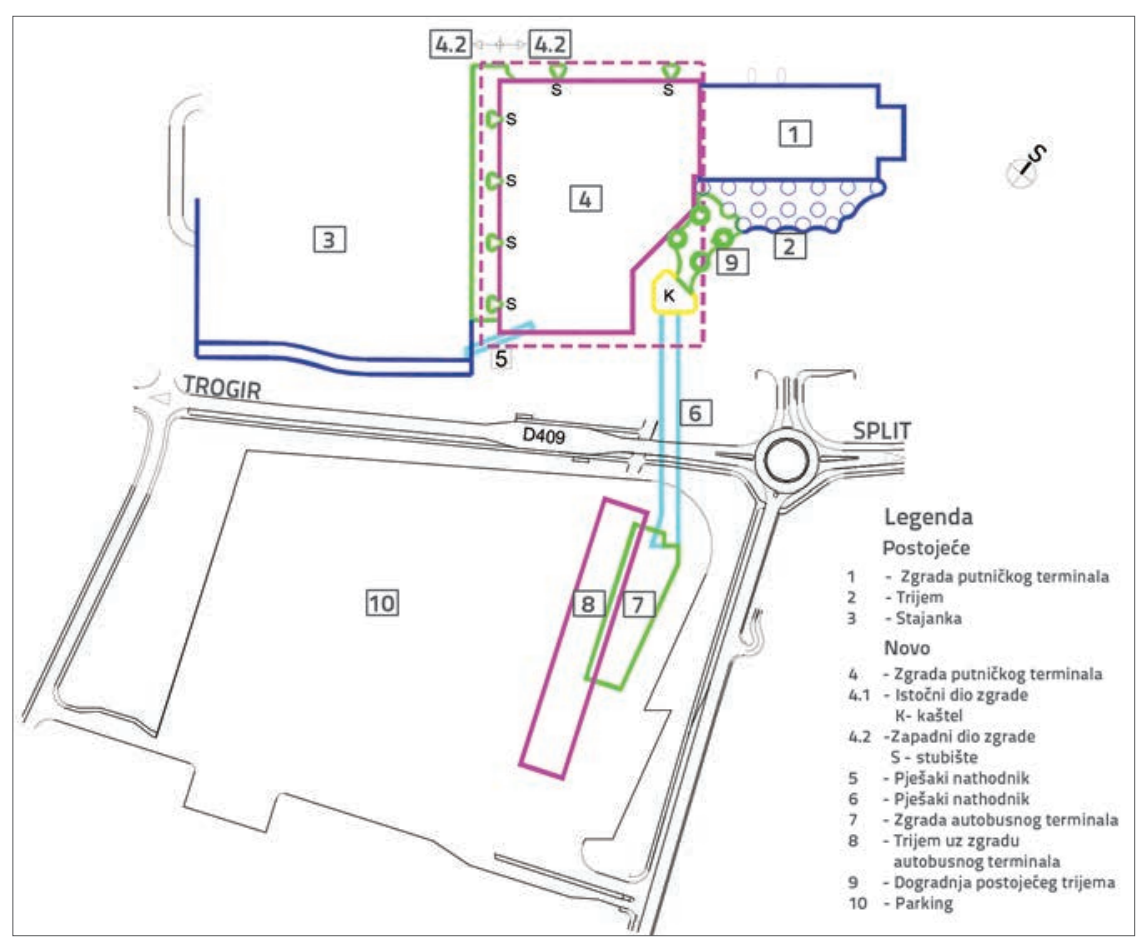

Figure 2. Main works to be realized according ot the new extension and rehabilitation design for Split Airport 
partly be modified. The building is made of the basement, ground floor, and first floor. The roof of the building is flat, with the cornice level at $10.3 \mathrm{~m}$ above the ground floor. Plan view dimensions of the building are $90 \times 47 \mathrm{~m}$. The existing shed in front of the existing building, measuring $95 \times 25 \mathrm{~m}$ in plan, will be extended at the southwest side all the way to the new building.

The new passenger departure/arrival building, situated between the existing building on the east side and the existing apron on the west side, will assume most functions of the existing building. The east part of the building is a compact glazed cube, with a flat and partly glazed roof. It has a basement, ground floor, first floor, and a gallery, with the roof cornice height extending to $14.75 \mathrm{~m}$ above the ground floor. The west part of the new building, located immediately next to the existing apron, has a basement storey only, and its height reaches the apron level.

The bus terminal building (passenger departure/arrival building), situated underneath the D409, is formed of the ground floor and the first floor, and its roof is flat and locally inclined. In front of

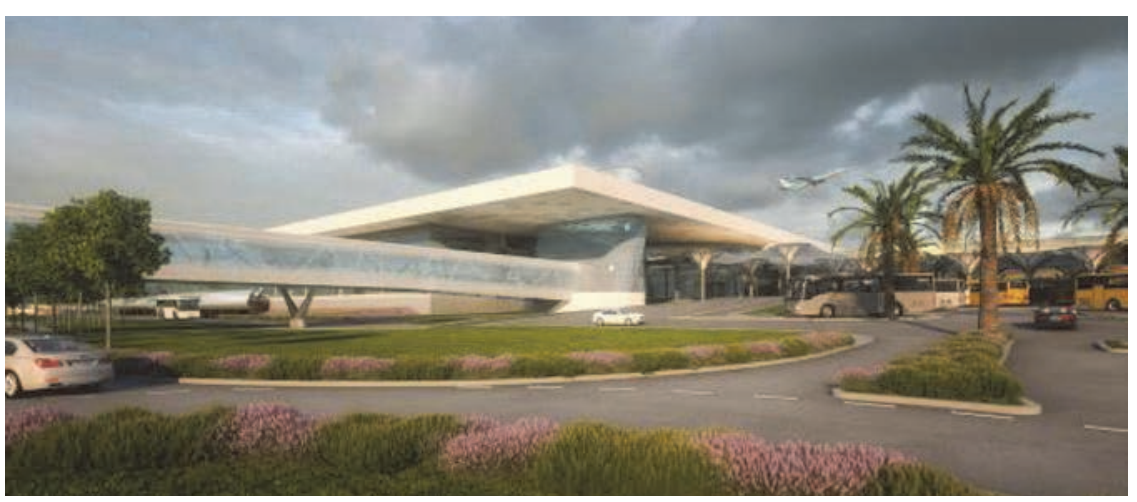

Figure 3. New passenger terminal building with pedestrian overbridge viewed from the D409 (southeast side)

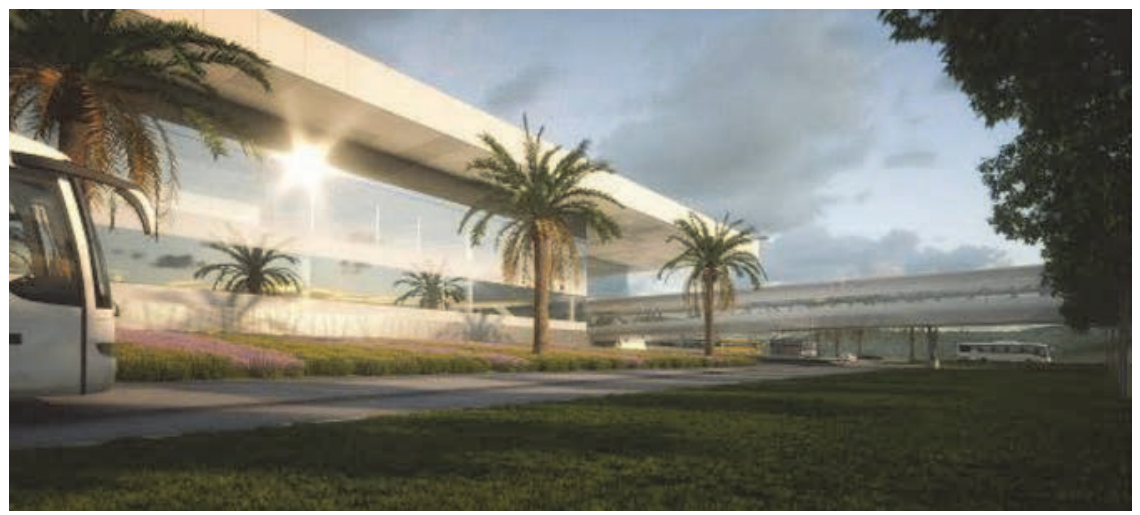

Figure 4. A view at the new passenger terminal building with pedestrian overbridge viewed from road D409 which covers the bus stop area and protects the passengers against adverse weather conditions. A closed glazed pedestrian overbridge, with moving steps for pedestrians, is planned as a means to ensure a "warm" link between the facilities situated to the north and south of the D409. Some views of the new passenger terminal building are presented in Figures 3 and 4.

By the end of April 2016, detailed designs were completed, the building permit was obtained, and almost all working designs were prepared. The collection of offers for the realisation of this project is currently under way. Some basic data relating to the civil engineering design, i.e. to the load-bearing structure of the extension and rehabilitation complex, are presented below [1, 2]. All new structures will lie on shallow foundations, as the soil is of solid quality, with a relatively high bearing capacity and low deformability. The structures to the north of the D409 will lie on relatively compact flysch formations, while those to the south of this road will be founded on well graded and densely compacted gravel.

The project is situated in the zone where the possible seismic activity is defined by the design soil acceleration of $0.223 \mathrm{~g}$ for the return period of 475 years. The site is located in a windy zone with the basic design speed of wind of $v_{b, 0}=30 \mathrm{~m} / \mathrm{s}$. The typical snow load on soil amounts to $s_{k}=0.45 \mathrm{kN} / \mathrm{m}^{2}$.

All structures have been designed for temperature variations, and the design of concrete and composite structures takes into account the shrinkage and creep of concrete. The structural model also includes the foundation soil, which is regarded as a stiff or permeable base (less favourable option was adopted). All structures and all elements have been tested for relevant combinations of all possible loads and actions, including control of limit states during use and the ultimate bearing capacity. The space model covering all load bearing structures (concrete, steel, composite, wooden, membrane, cable) that are connected to one another, was used in the analysis of individual structures. Usual construction materials were used. Concrete classes C $30 / 37$, C 40/50, and locally C 50/60, were used. The quality of steel reinforcement is $\mathrm{B} 500 \mathrm{~B}$. The quality of structural steel is $\mathrm{S} 355 \mathrm{~J} 2+\mathrm{N}$. Pretensioned cables used at shed are made of stainless steel A4 (AISI 316), with the hardness of $\geq 1770 \mathrm{MPa}$. The grade of laminated timber girders is GL24h.

All concrete structures are to be realized as monolithic structures. Most connections at steel structures will be welded, while bolted connections will be used to a much lesser extent. The grade of steel structures will be EXC3 and EXC4, as specified in EN 1090-2 [3]. Corrosion protection of steel surfaces involves the use of coatings in accordance with EN 12944 [4]. Fire protection of steel structures will be ensured through the use of protective fire-resistant coatings. All analyses were made in accordance with prevailing regulations, standards [3 - 13], and rules of professional practice. 


\section{Presentation of bearing structures}

\subsection{New passenger terminal building}

\subsubsection{East part of the building}

This part of the new passenger terminal building measures 95 $x 122 \mathrm{~m}$ in plan, and is formed of four storeys ( $\mathrm{Po}+\mathrm{Pr}+\mathrm{K}+\mathrm{G})$. The roof of the building measures $100 \times 137.5 \mathrm{~m}$ in plan. The building has been designed as a single structural system. A part of the building's interior is shown in Figures 5 and 6.

The main load bearing structure of the building is a complex space structure formed of reinforced concrete, structural steel, and laminated timber. The space model of the structure is shown in Figure 7.
The basic bearing structure of the building is formed of reinforced concrete up to the roof level. The roof structure of the building is made of steel and, to a lesser extent, of timber. The structure of six staircases connecting the building with the apron is made of steel, and the same material is used for the structure of the tower connecting the building with the pedestrian overbridge. First three forms of free oscillation of the building are shown in Figure 8. A significant general influence of torsion in the space structure is due to unsymmetrical stiffness and distribution of masses along the building's height. As shown in the figure, the first and third form of free oscillations of the building are mostly torsional and to a lesser extent translational, while the second form of free oscillation is mostly translational. The structure of basic functional-structural parts of the building is briefly described below.

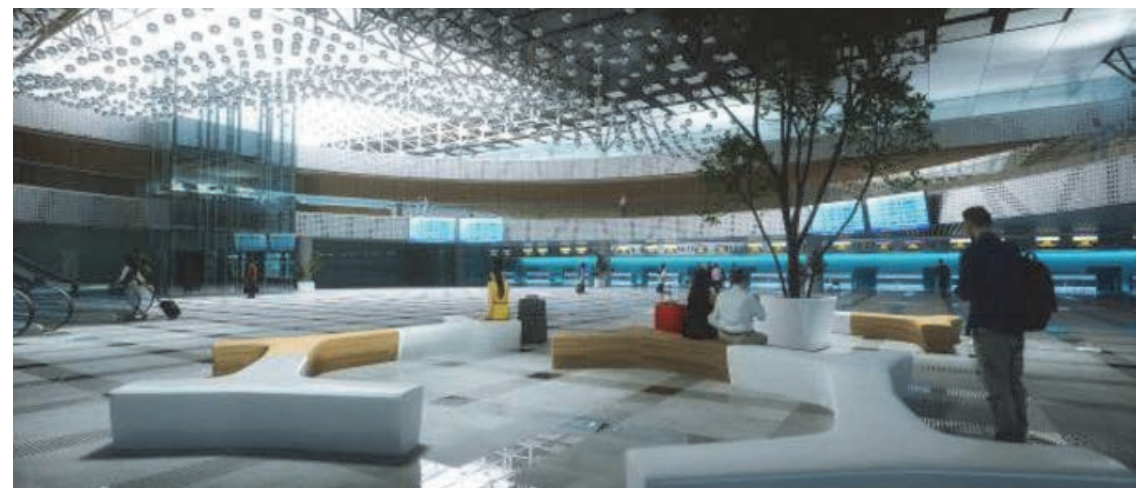

Figure 5. Inside view of the new passenger terminal building, ground floor

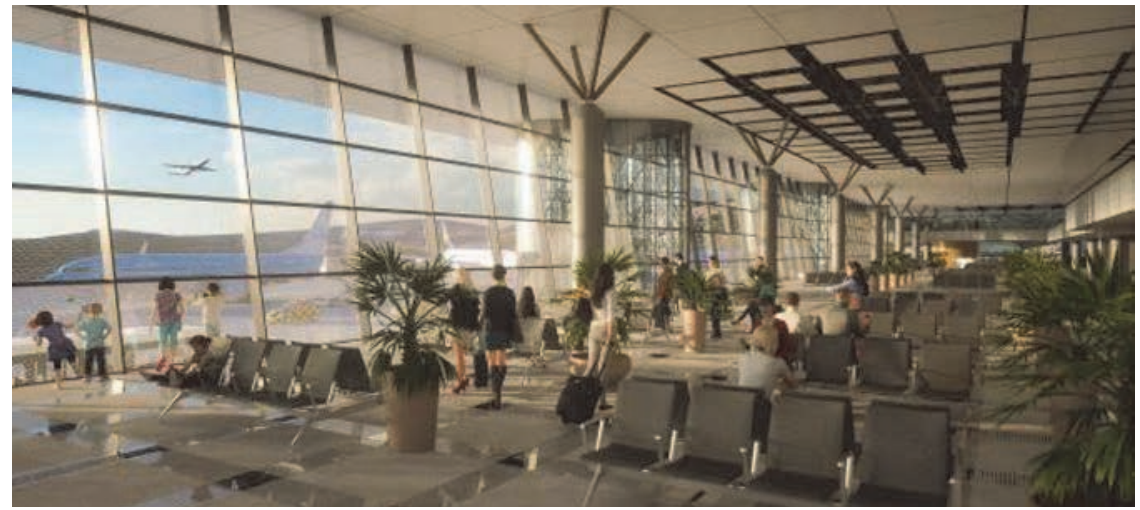

Figure 6. Inside view of the new passenger terminal building, first floor

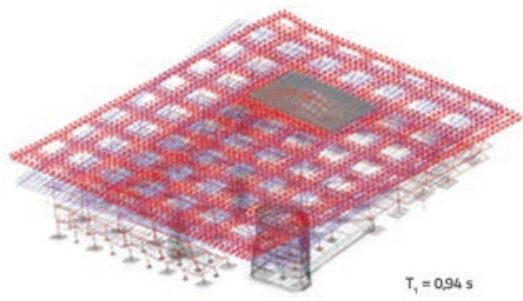

$T_{1}=0.94 \mathrm{~s}$

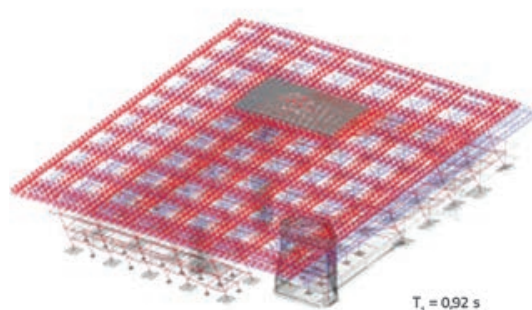

$T_{1}=0.92 \mathrm{~s}$

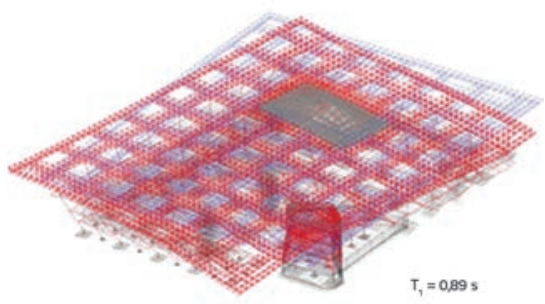

Figure 8. First three forms of free oscillation at eastern part of the new passenger terminal building

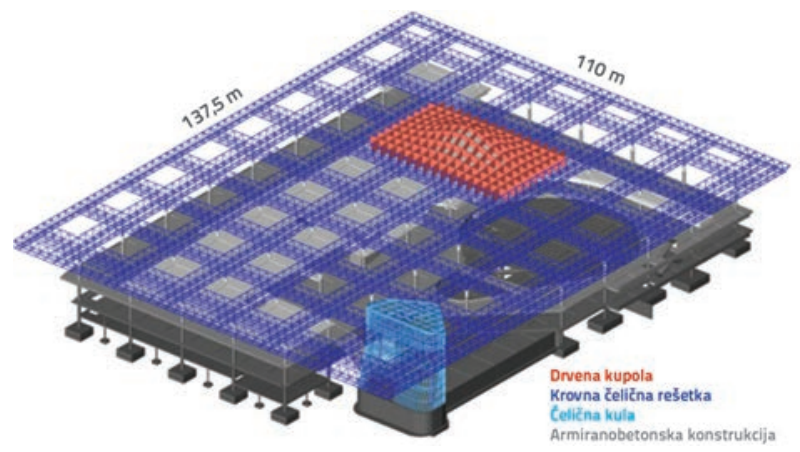

Figure 7. Global structural space model of east part of new passenger terminal building

\section{Reinforced-concrete structure}

The main reinforced-concrete structure of the building is formed of columns spaced at $15 \times 15$ m axis-to-axis intervals and main beams oriented toward the columns, and they together form a space frame for the transfer of vertical and horizontal loads. The horizontal floor structure is formed of cross reinforced concrete slabs $20 \mathrm{~cm}$ in thickness, which lean onto main frame beams and secondary beams at half distance between the columns (slab support span measures $7.5 \times 7.5 \mathrm{~m}$ ). Columns are of circular cross-section, and they vary in diameter from $1.20 \mathrm{~m}$ (in basement) to $0.80 \mathrm{~m}$ (under the roof structure). Main and secondary beams measure $1.2 \mathrm{~m}$ in height ( $8 \%$ of the span). Main beams and secondary beams are 0.6 and $0.4 \mathrm{~m}$ wide, 
respectively. Reinforced-concrete peripheral walls in basement are separated from the main frame structure so as to reduce forces in frame due to temperature changes and concrete shrinkage, and to soften the global building structure in order to reduce generation of seismic forces.

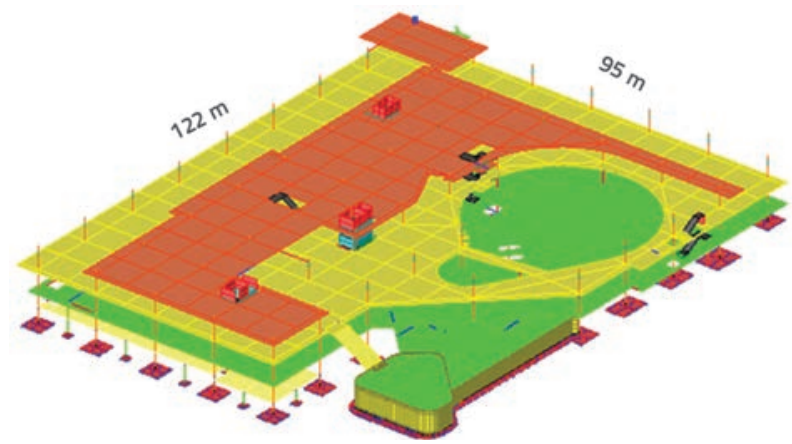

Figure 9. Space model of reinforced-concrete structure at eastern part of new passenger terminal building

\section{Steel roof structure}

The steel roof structure is a flat horizontal space truss $2 \mathrm{~m}$ in height (Figures 10 and 11). It is linked by hinged connection to columns of the concrete frame. As all concrete columns of the frame do not extend all the way to the roof, the distance between the steel truss supports varies from $15 \mathrm{~m}$ to $45 \mathrm{~m}$.

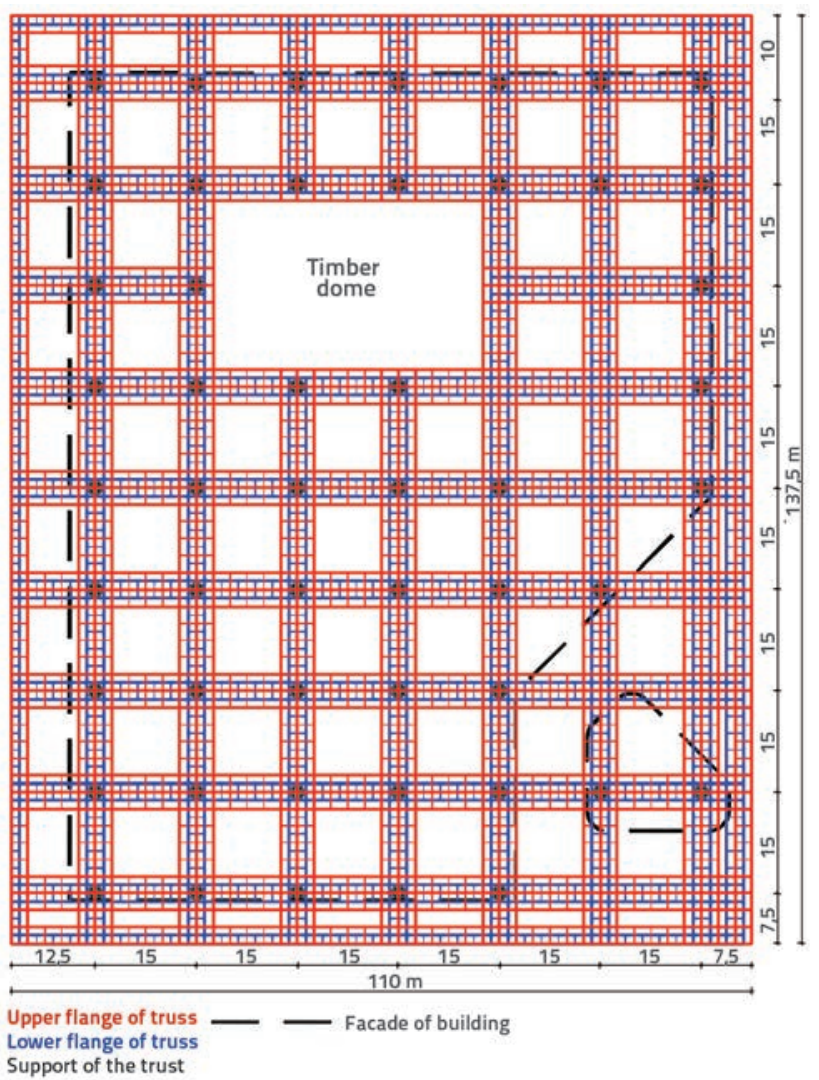

Figure 10. Plan view of roof truss at the eastern part of the new passenger terminal building
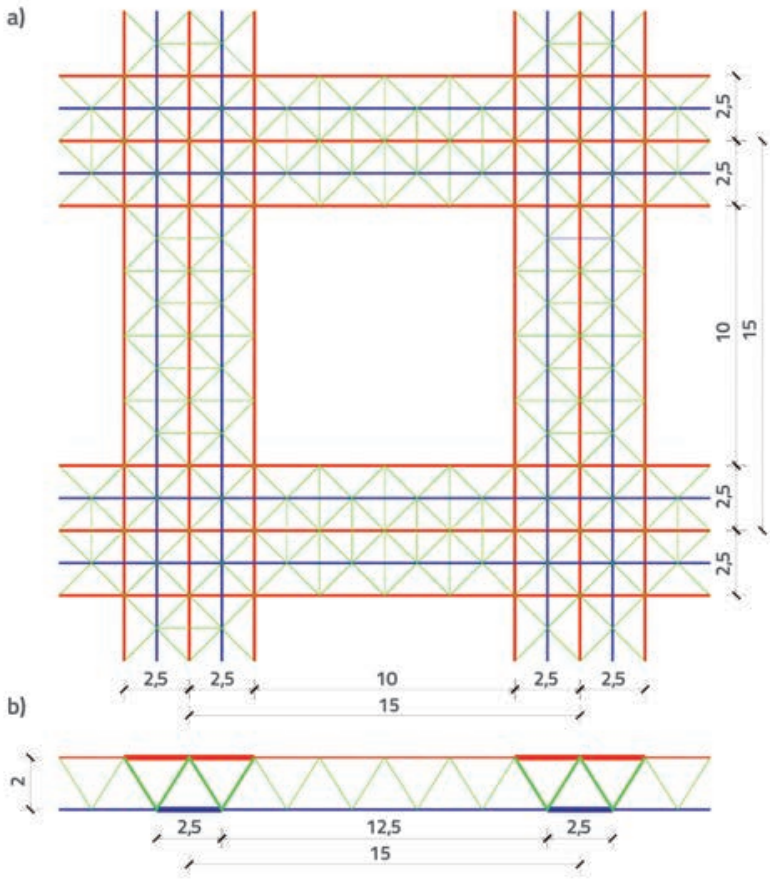

c)

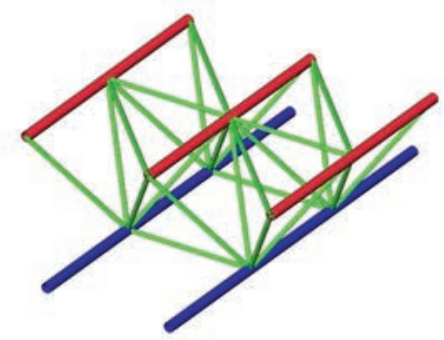

Figure 11. Typical roof truss segment: a) Plan view; b) Vertical section; c) Axonomerty of truss segment

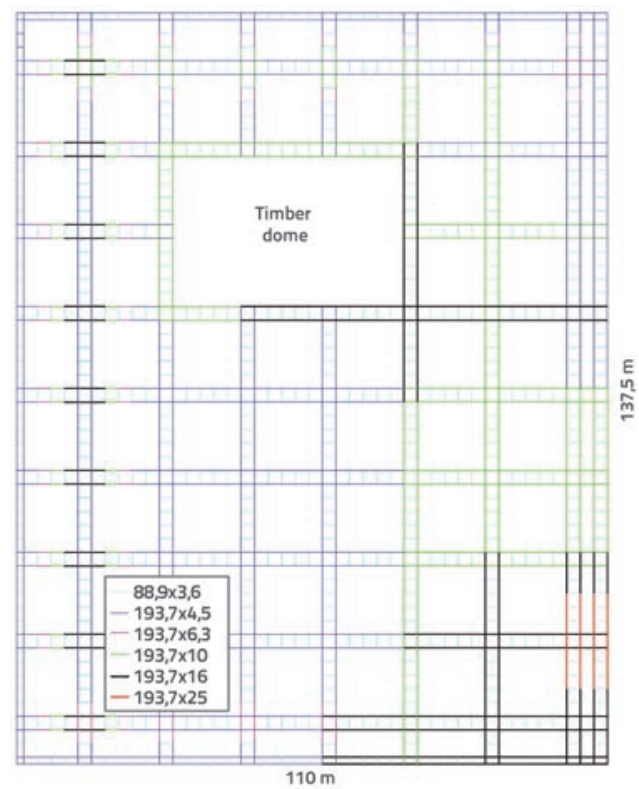

Figure 12. Cross-sectional dimensions of circular pipes at the bottom roof-truss flange [mm] 
The roof structure has large cantilevers extending beyond the plan view dimensions of the floor. For that reason, and due to the fact that the timber dome above a $25 \times 40$ m opening leans onto the steel truss, a great difference in cross-section dimensions of truss members is inevitable (Figure 12). The truss with members oriented solely toward supports (columns) has been adopted in order to reduce the number of members in the truss, to speed-up construction, and to reduce the roof price. A trapezial truss girder $2 \mathrm{~m}$ in height has been formed in these directions, with three longitudinal members in the upper flange that are spaced at 2.5 m intervals, two longitudinal members in the lower flange spaced at the same distance, and other necessary members (diagonals). Roof truss leans onto columns using a hinged connection, via four inclined bifurcated members (Figure 6).

Truss members are steel pipes ranging from 88.9 to $193.7 \mathrm{~mm}$ in diameter (members most exposed to load above column). The truss has been calculated for the cases of hinged connection and rigid connection of members in nodes so as to take into account the way in which the global safety of the truss is affected by possible different technological node solutions during realization. In addition to forces due to vertical load and wind load, forces in truss are also greatly influenced by temperature changes and concrete shrinkage.

A typical shallow truss structure made of open steel sections (Figure 13) is planned in the part of the roof extending beyond roof truss members, in zones measuring $10 \times 10 \mathrm{~m}$ in plan. This structure is freely supported by main-truss nodes and it does not take part in the global roof-carrying system.

Figure 13. Truss structure in roof beyond roof truss members

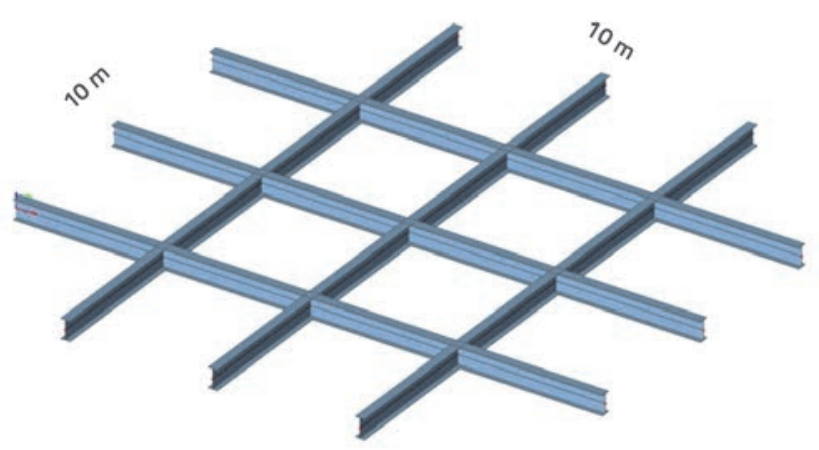

Wooden dome

A glazed ribbed dome made of laminated timber girders is planned on a part of the building's roof, in the zone measuring $25 \times 40 \mathrm{~m}$ in plan (Figures 7 and 10). The girders are curbed and they are of variable height and complex geometry (Figure 14). All girders measure $20 \mathrm{~cm}$ in width. At their ends, the girders lean onto the top and bottom flanges of the steel roof truss. The vertical reaction is transferred in truss nodes at the top flange, while horizontal girder reaction is transferred in nodes at the bottom flange. The shape of the dome is adjusted to the shaping requirement. Some dome calculation results are presented in Figure 15.

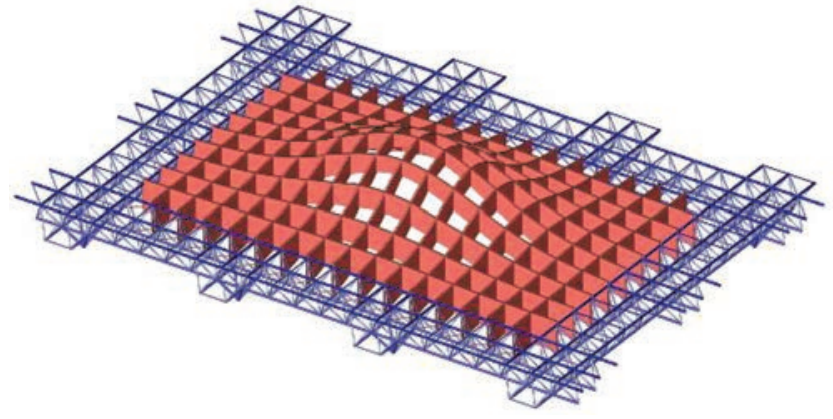

Figure 14. Space model of ribbed timber dome structure

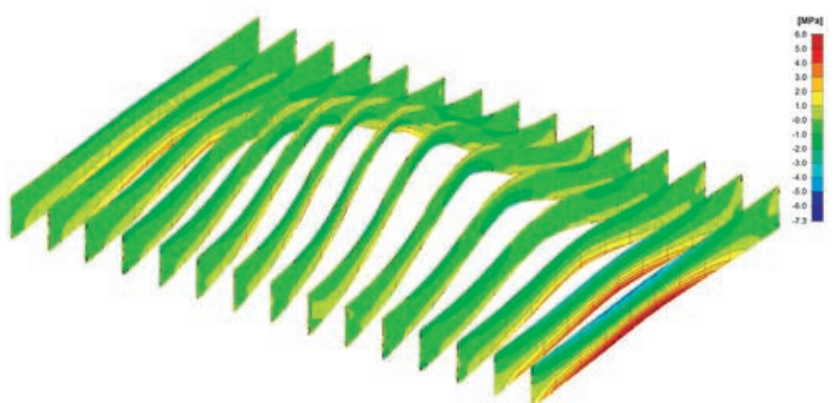

Figure 15. Longitudinal stress in shorter-direction girders for relevant load combination [MPa]

\section{Steel staircases connecting main building and apron}

Six closed laterally glazed staircases will connect the main building and the apron; four identical ones next to the west façade and two similar ones next to the north façade (Figure 16).

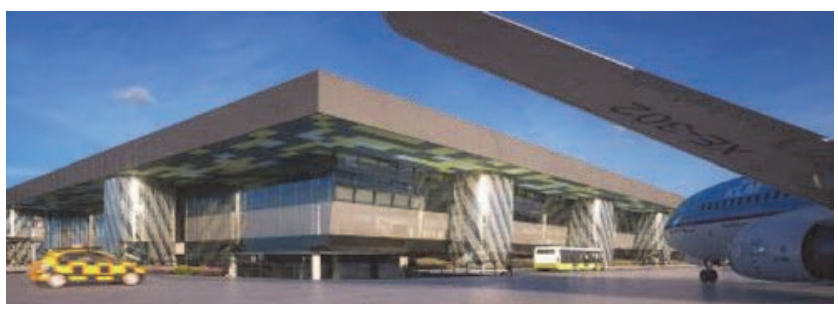

Figure 16. New passenger terminal building viewed from the northwest (existing apron)
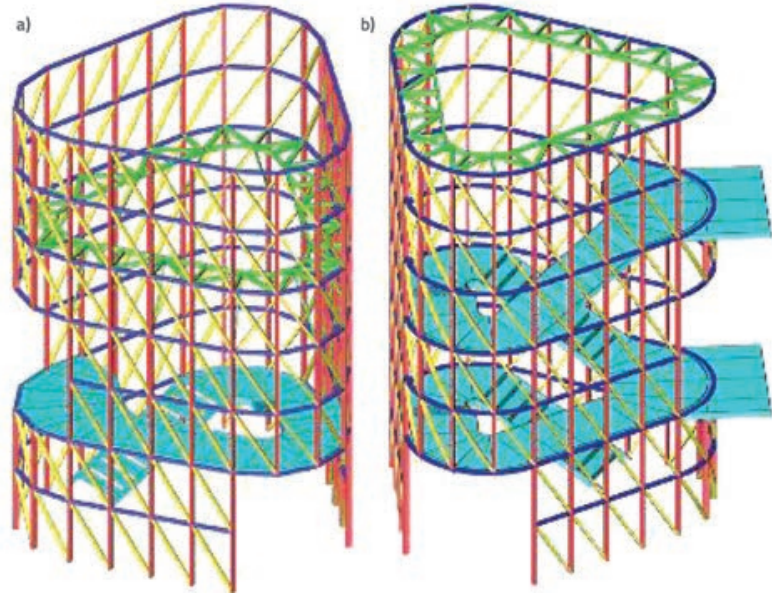

Figure 17. Space model of a typical staircase at the west façade (left side) and north façade (right side) 
The staircases protrude from the main building. The main external structure of the staircase is a welded steel space frame made of rectangular pipes (Figure 17). Staircase flights are a steel-made space structure formed of welded steel sheets, which leans at some points onto the external staircase structure.

\section{Tower connecting main building and pedestrian overbridge}

The tower spreads from the ground floor to above the building roof level, and it is glazed from all sides. It is characterized by complex curbed geometry at the façade (Figure 18).

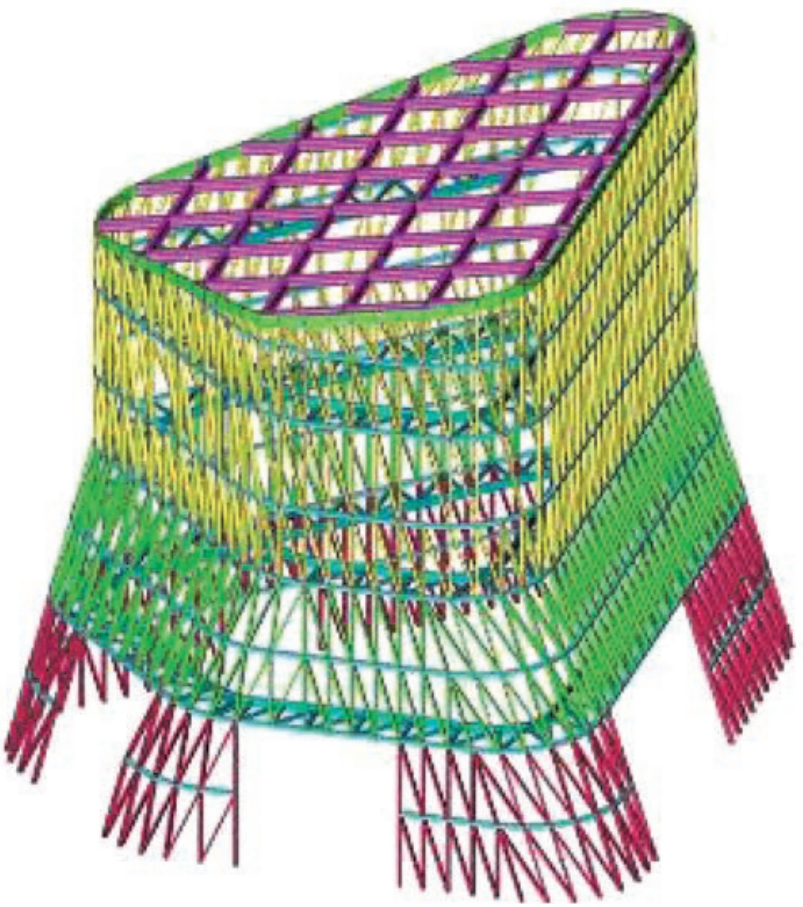

Figure 18. Space model of steel structure of the tower

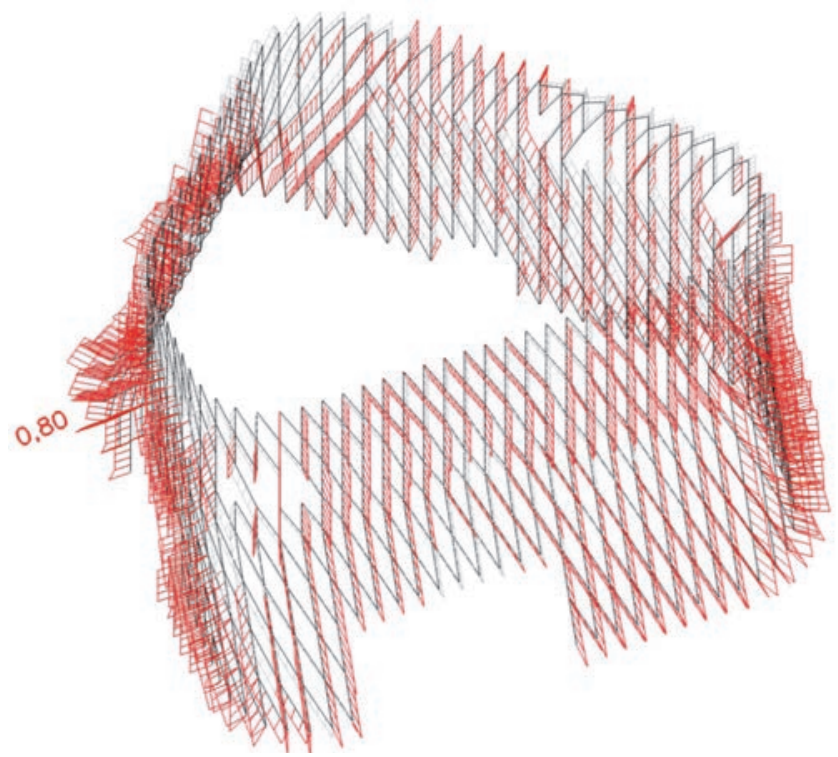

Figure 19. Use ratio of inclined members at the tower facade
The façade structure is formed by a steel truss space frame made of rectangular welded steel pipes. To ensure stability of this slender steel structure, three ring trusses (stiffeners) will be positioned along the tower height. The roof structure of the tower is an in-plane truss made of IPE steel sections. The tower structure protrudes from the steel roof structure of the building. Some tower structure analysis results are presented in Figure 19.

\subsubsection{West part of the building}

The west part of the building measures $122 \times 18 \mathrm{~m}$ in plan and is situated next to the existing apron. It consists of a single storey (level) divided into four separate units. The main load-carrying structure is a reinforced-concrete system formed of a space frame and cross reinforced concrete slabs. Steel staircases connecting the bus stop and the new main (east-side) building are situated on top of the building. Structural space model of one unit of the building is presented in Figure 20.

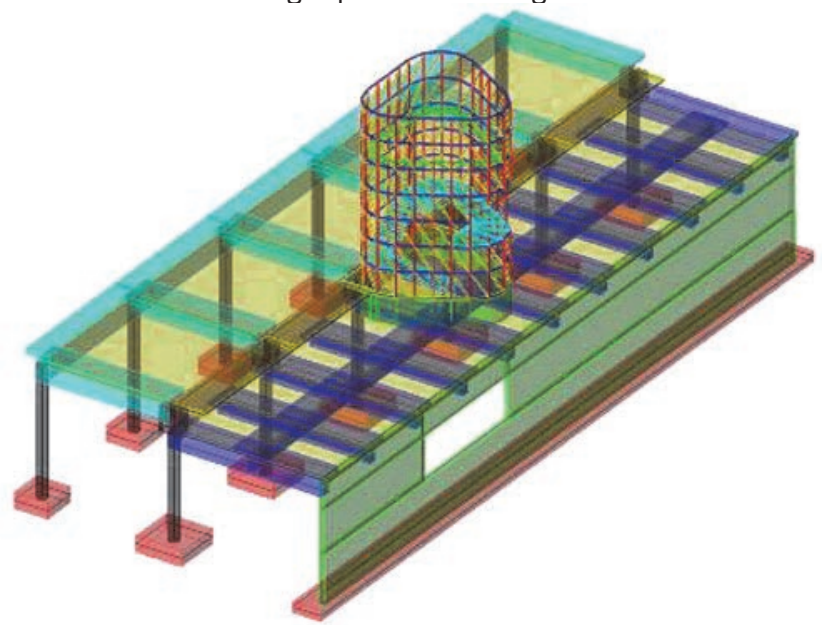

Figure 20. Structural space model of west part of the main building - Unit 2

\subsection{Shed next to the bus terminal building}

The shed is a single storey facility measuring approximately 140 x $22 \mathrm{~m}$ in plan and approximately $7.5 \mathrm{~m}$ in height. It is formed as a single unit (Figures 21 and 22). The load bearing structure of the shed is original and complex. The cover is a tensioned membrane spread above the steel roof structure. The main load bearing structure of the shed is a space frame. Beams and top part of columns are welded steel sheet girders. Beams are joined in hinged connection in half span of columns, in transverse and longitudinal directions. The bottom part of the columns and foundations are made of reinforced concrete. The braces between membrane tops in spans and bottom ties are made of wood. The drainage of the membrane is solved through the centre of columns. The membrane is supported at appropriate points above columns and above the wooden bracing in span, and linearly along external pretensioned cables. The membrane curvature has been obtained by proper distribution of its linear 


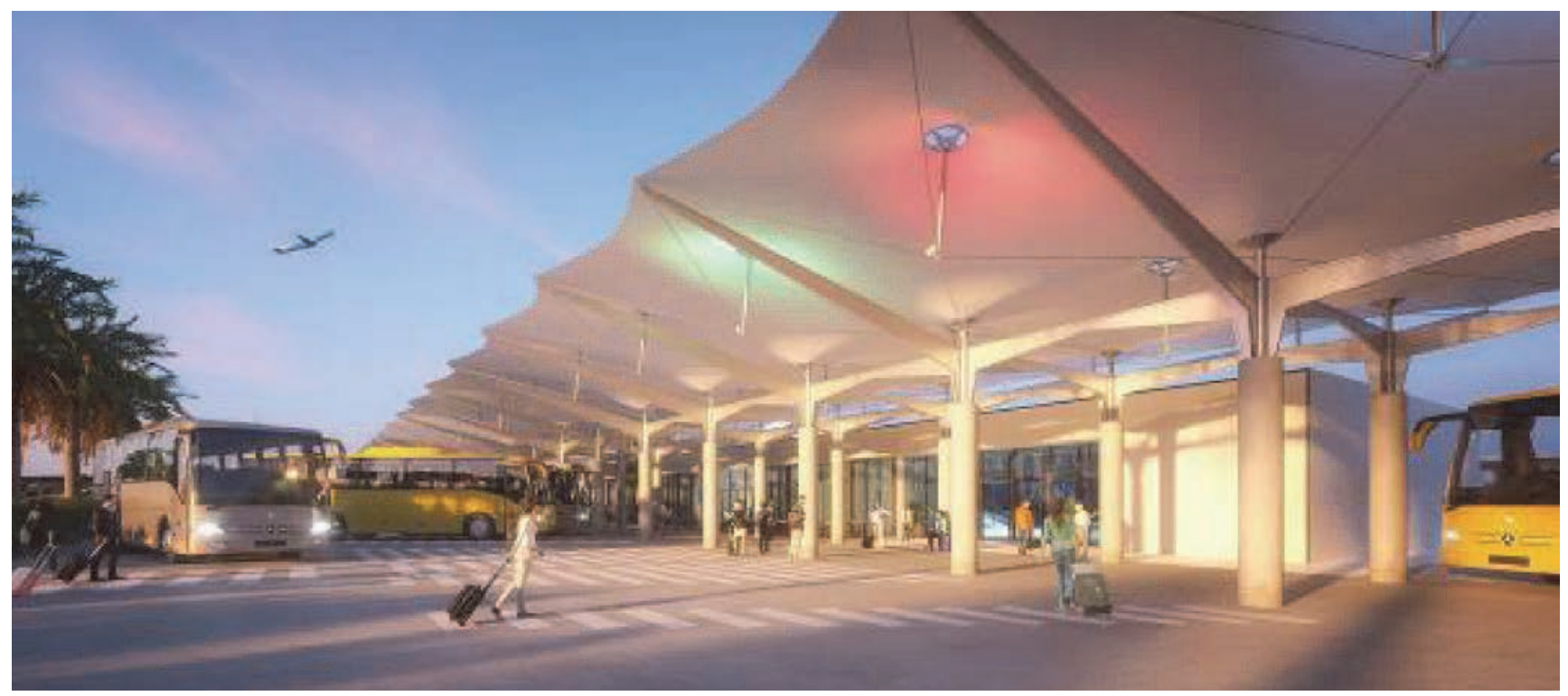

Figure 21. New shed in front of the bus terminal building

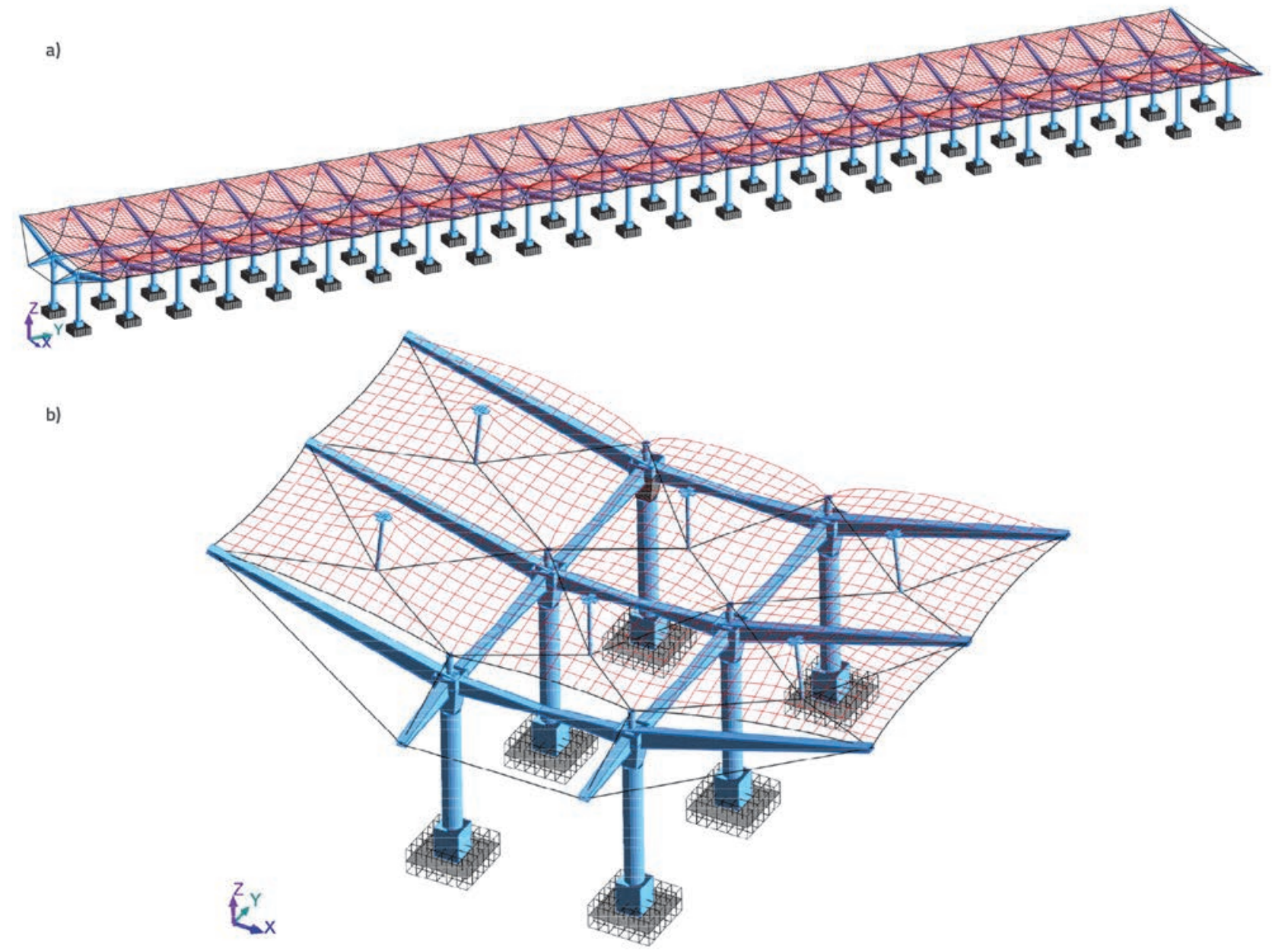

Figure 22. Space model of shed structure in front of the bus terminal building: a) Complete structure; b Structure detail on edges 


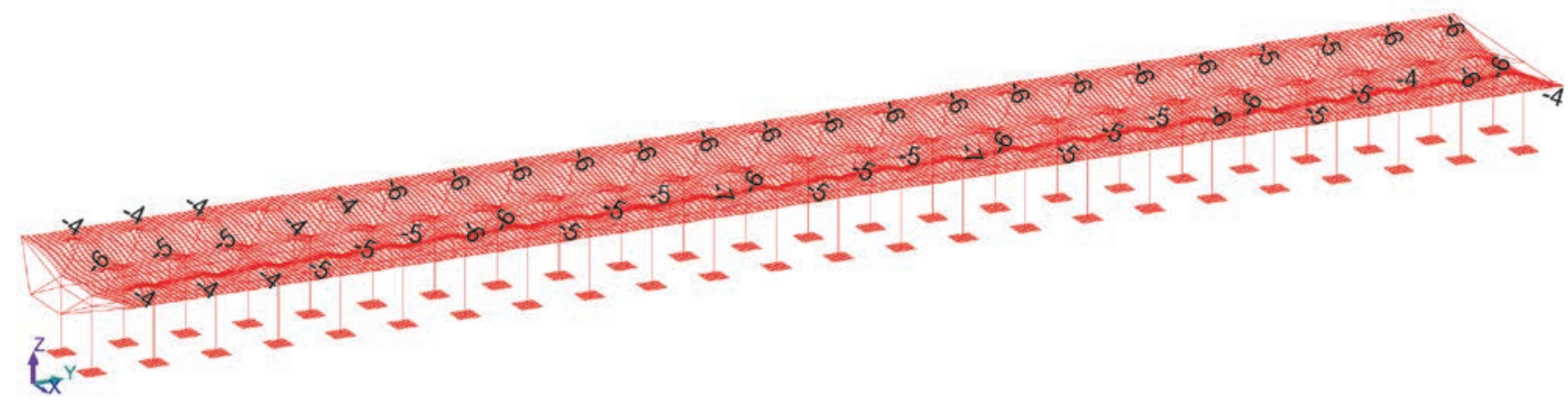

Figure 23. Stress in membrane due to self-weight and prestressing [MPa]

and point-based supports. The membrane canvas is made of high-capacity glass fibres (PTFE) whose base and cover present different physical properties.

Positive experience in the design and realisation of the existing shed (membrane) in front of the existing passenger terminal building was used during calculation of the membrane and the entire shed. In fact, this structure, built approximately a decade ago, has proven to be of an outstanding quality. The membrane is fully preserved and it did not lose its initial shape. The overall structure of the new shed is complex. It was calculated using a linear model for material, and a nonlinear model with regard to geometry. The analysis was first conducted for the initial membrane tensioning and continuous load, and then for all other relevant loads and actions. Some calculation results are presented in Figure 23.

\subsection{Bus terminal building}

The building is a two-storey structure (GF $+\mathrm{FF}$ ) and it measures approximately $80 \mathrm{~m}$ in length and up to $28 \mathrm{~m}$ in width. The main load-carrying structure is of mixed type (Figure 24): for the most part it is made or reinforced-concrete while the remaining parts are made or steel and steel-concrete composite.

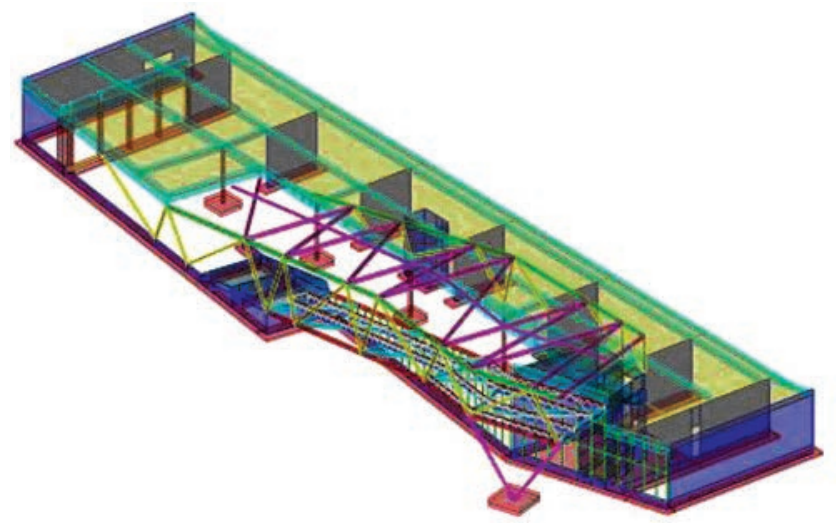

Figure 24. Space model of bus terminal building

The reinforced-concrete structure is dominantly a frame structure, and partly it is composed of concrete walls. The steel structure at the connection with pedestrian overbridge and next to the eastern façade is analogous to the steel structure of the pedestrian overbridge. A steel $\mathrm{V}$-column in the direction of the overbridge axis is planned at the connection between the building and the overbridge. Column elements are spindle pipes with hinges on the top and bottom parts. As the building is realised as a single unit and is partly composite, the concrete shrinkage and temperature changes exert a great influence on internal forces.

\subsection{Pedestrian overbridge connecting new passenger terminal building and bus terminal building}

The overbridge (Figures 3 and 4 ) has three openings measuring $40.7+42.0+32.4 \mathrm{~m}=115.1 \mathrm{~m}$. Its load bearing system is continuous, closed and glazed. The upper structure and top parts of columns are made of steel, while the bottom parts of columns and foundations are made of concrete. The overbridge is of variable width in plan $(8.25-13.0 \mathrm{~m})$, and it is of variable height in longitudinal disposition (5.0 - $6.3 \mathrm{~m})$. The upper structure of the overbridge is a space truss frame (Figure 25) with stiff nodes.

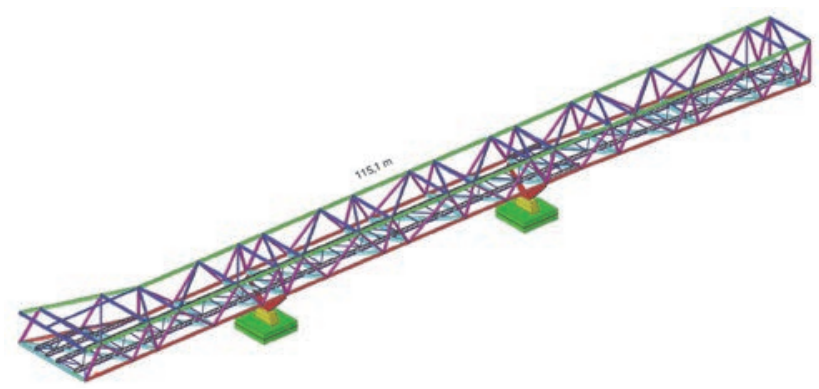

Figure 25. Space model of pedestrian overbridge connecting new passenger terminal building and bus terminal building

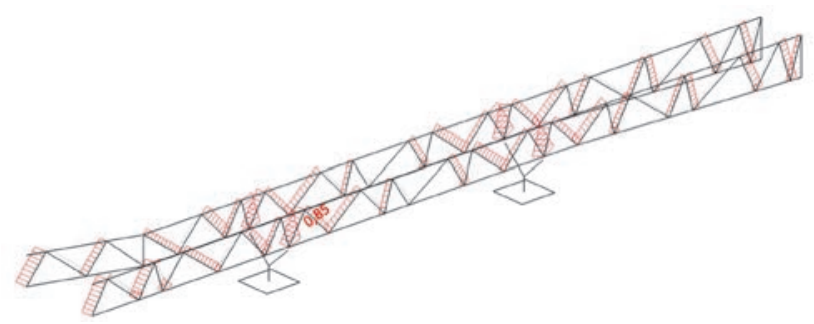

Figure 26. Use ratio for vertical truss members of the overbridge across the D409 
Vertical truss diagonals are of variable inclination, to comply with shaping requirements. The diagonals will be lighted at night for decoration purposes. The frame members are made of typical hot-processed rectangular pipes. Horizontal forces along the bridge are transferred by columns, while in transverse direction forces are transferred by columns and support structures on the new buildings. Columns are $\mathrm{V}$-shaped in transverse disposition, and are linked via hinged connection with the upper structure. Some analysis results for this overbridge are presented in Figure 26.

\subsection{Pedestrian overbridge connecting new passenger terminal building and apron}

This overbridge is also closed and it measures approximately $35 \mathrm{~m}$ in length and $3.3 \mathrm{~m}$ in width. The upper structure of the overbridge is made of steel, and the substructure is made of reinforced concrete (Figure 27). The structure and other overbridge solutions are analogous to the solutions adopted for the overbridge connecting the new passenger terminal building and the bus terminal building.

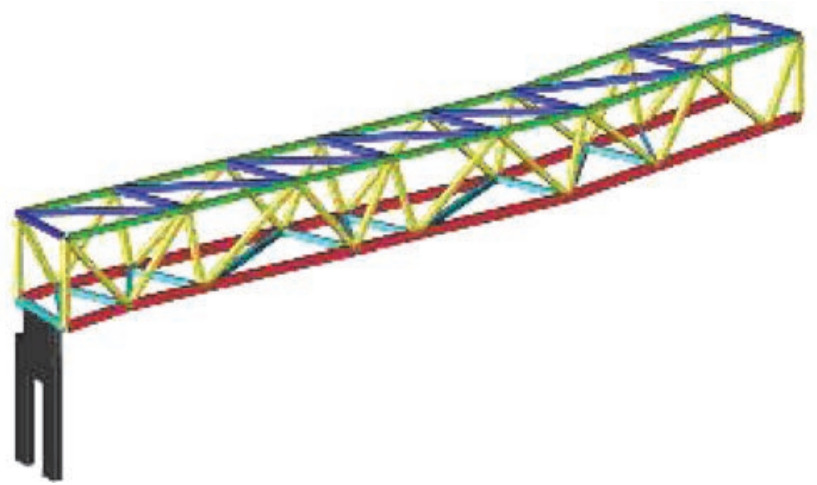

Figure 27. Pedestrian overbridge space model

\subsection{Extension of shed in front of the existing passenger terminal building}

The existing shed in front of the existing passenger terminal building (Figure 28) will be extended in the southwest direction for approximately 950 square meters, and solutions similar to those adopted for the existing shed will be used (tensioned membrane above steel members).

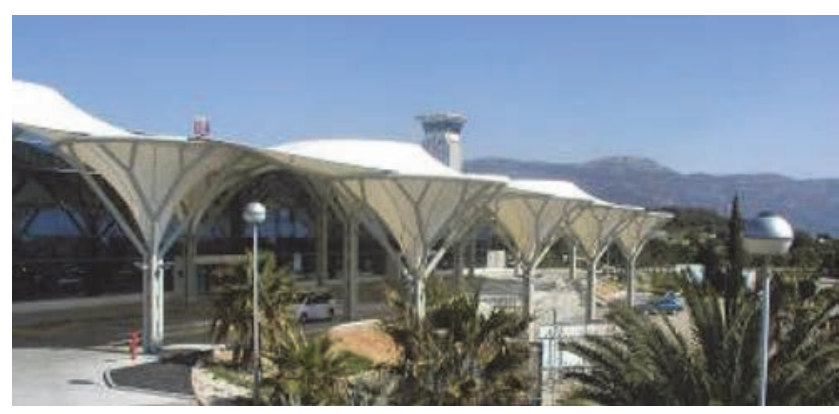

Figure 28. Existing shed viewed from southwest
On the south side, the membrane is spread between pretensioned cables, anchored in the tower. The space model of the extension structure is presented in figure 29 , while some calculation results are given in Figure 30.

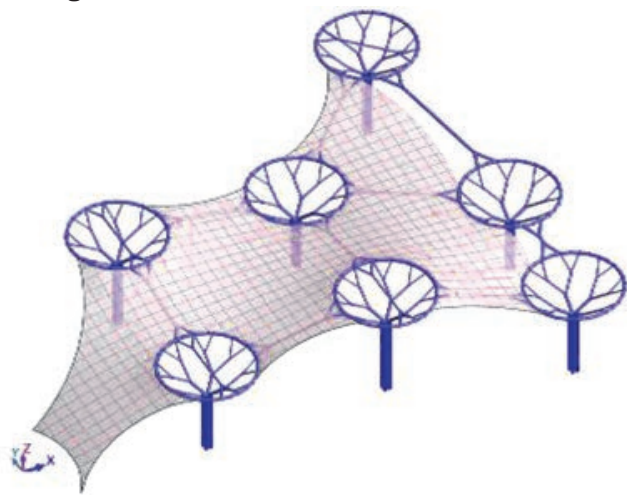

Figure 29. Space model of extension to the existing shed

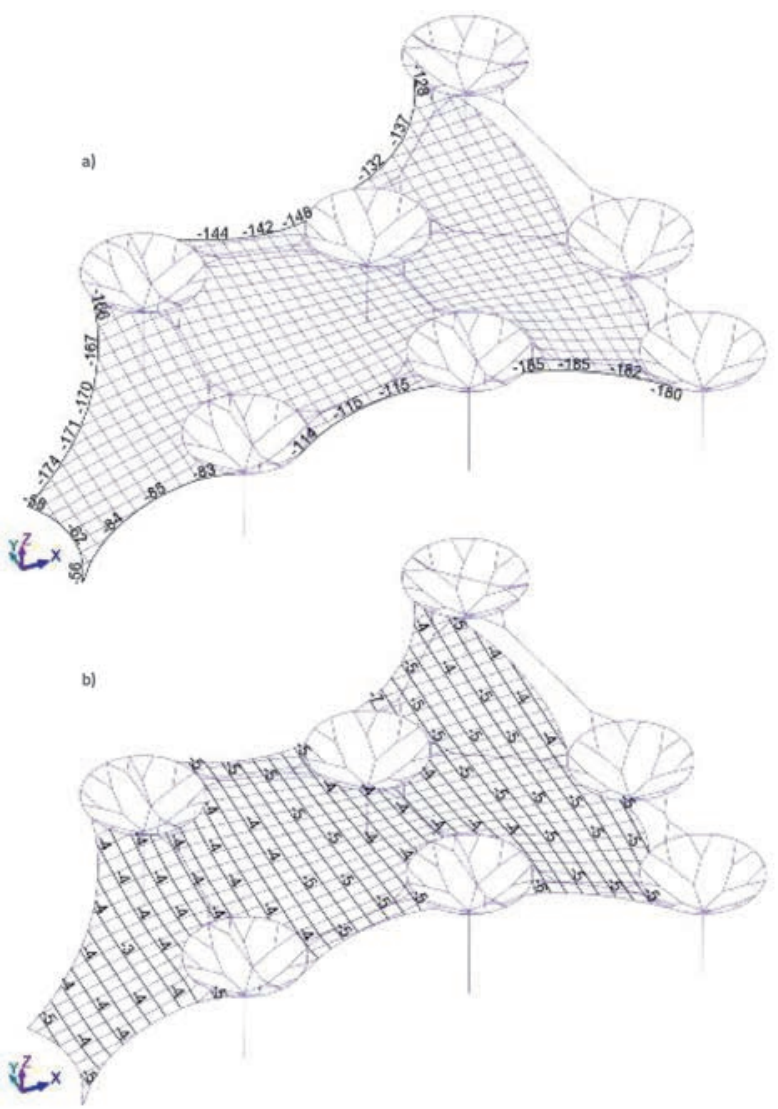

Figure 30. Extension of the existing shed - Stress [MPa] in external cables (top) and membrane (bottom) due to self-weight and prestressing

\subsection{Rehabilitation of the existing passenger terminal building}

Based on the new rehabilitation design, the existing passenger terminal building requires, next to the east façade of the new terminal building, several interventions on its concrete, 
composite and steel structure. In fact, the new design calls for creation of several new openings and elimination of a number of existing openings in the existing walls and floor structures, creation of new staircases and elevators, rehabilitation of walls and foundations at the contact with the new building (new building is buried by about $3 \mathrm{~m}$ as compared to the existing structure), etc.

\section{Project documentation}

Architectural design: VV-project d.o.o. Split designers: Ivan Vulić, M.Arch. Ivan Radeljak, M.Arch.

Civil engineering design: Radnić d.o.o. Split designer: Prof. Jure Radnić, PhD. CE

Mechanical engineering design: TUB d.o.o. Split designer: Ivo Žuvela, M.Eng. ME (water supply and drainage)

\section{Mechanical engineering design:} designer: Vlado Nigojević, M.Eng. ME (sprinkler and thermal installations) SIGET-Project d.o.o. Zagreb designer: Milenko Kasalo, M.Eng. ME (lifts and conveyor belts)

Electrical engineering design: ELTEAM-71 d.o.o. Split designer: Vlado Šokota, M.Eng. EE
Design of traffic areas: Trivium d.o.o. Split designer: Miroslav Jakovčević, MCE

Inspection of detailed design with regard to mechanical resistance and stability:

- metal structures: Prof. Boris Androić, Ph.D. CE

- concrete structures: Darko Fadić, M.Eng. CE

- timber structures: Đuro Nižetić, M.Eng. CE

\section{Conclusion}

The structure of the main load-bearing structure of the passenger terminal extension at Split Airport is for the most part innovative and complex. It comprises various structural types, load-bearing systems, materials and zones. The structural design was prepared in compliance with applicable regulations, standards and professional rules of practice, and in full conformity with modern technical levels. It is expected that the realization of this project will constitute a valuable contribution to the development of building profession.

\section{Acknowledgement}

The assistance provided by the client Zračna luka Split d.o.o. through submittal of computer visualisations of designed structures, as created by independent film artist Mr. Boris Goreta, is greatly acknowledged.

\section{REFERENCES}

[1] Radnić d.o.o., Split: Glavni projekt konstrukcija dogradnje i rekonstrukcije putničkog terminala Zračne luke Split, T.D. 09/2014/JR, projektant: prof. dr. Sc. Jure Radnić

[2] Radnić d.o.o., Split: Izvedbeni projekt konstrukcija dogradnje i rekonstrukcije putničkog terminala Zračne luke Split, T.D. 09/2014/JR-IZV, projektant: prof. dr. Sc. Jure Radnić

[3] HRN EN 1090-2:2011, Izvedba čeličnih i aluminijskih konstrukcija - 2. dio: Tehnički zahtjevi za čelične konstrukcije, Zagreb, 2011.

[4] HRN EN ISO 12944:1999, Boje i lakovi - Zaštita od korozije čeličnih konstrukcija zaštitnim sustavima boja, Hrvatski zavod za norme, Zagreb, 1999.

[5] HRN EN 1990:2011, Eurokod O: Osnove projektiranja konstrukcija + Nacionalni dodatak, Hrvatski zavod za norme, Zagreb, 2011.

[6] HRN EN 1991:2012, Eurokod 1: Djelovanja na konstrukcije + Nacionalni dodaci, Hrvatski zavod za norme, Zagreb, 2012.

[7] HRN EN 1992:2013, Eurokod 2: Projektiranje betonskih konstrukcija + Nacionalni dodaci, Hrvatski zavod za norme, Zagreb, 2013.
[8] HRN EN 1993:2014, Eurokod 3: Projektiranje čeličnih konstrukcija + Nacionalni dodaci, Hrvatski zavod za norme, Zagreb, 2014.

[9] HRN EN 1994:2012, Eurokod 4: Projektiranje spregnutih čeličnobetonskih konstrukcija + Nacionalni dodaci, Hrvatski zavod za norme, Zagreb, 2014

[10] HRN EN 1995:2013, Eurokod 5: Projektiranje drvenih konstrukcija + Nacionalni dodaci, Hrvatski zavod za norme, Zagreb, 2013.

[11] HRN EN 1996:2012, Eurokod 6: Projektiranje zidanih konstrukcija + Nacionalni dodaci, Hrvatski zavod za norme, Zagreb, 2012.

[12] HRN EN 1997:2012, Eurokod 7: Geotehničko projektiranje + Nacionalni dodaci, Hrvatski zavod za norme, Zagreb, 2012.

[13] HRN EN 1998:2011, Eurokod 8: Projektiranje potresne otpornosti konstrukcija + Nacionalni dodaci, Hrvatski zavod za norme, Zagreb, 2011. 